\title{
Domestication and Foreignization in the Chinese-English Translation
}

\section{Of the White Paper on Anti-corruption}

\author{
Yi Chen (Corresponding author) \\ School of Humanities, Beijing Unviersity of Posts and Telecommunications \\ 10 Xi Tu Cheng Road, Beijing 100876, China \\ Tel: 86-10-13021095785Ｅ-mail: norachenyi@yahoo.com
}

Xuan Miao

School of Humanities, Beijing Unviersity of Posts and Telecommunications

10 Xi Tu Cheng Road, Beijing 100876, China

Tel: 86-10-15810991889 E-mail: sunnie_xm@163.com

\author{
Received: April 20, 2012 \\ Accepted: May 15, 2012 \\ Published: June 15, 2012 \\ doi:10.5430/wjel.v2n2p10 \\ URL: http://dx.doi.org/10.5430/wjel.v2n2p10
}

The research is supported by the Fundamental Research Funds for the Central Universities2012RC1105.

\begin{abstract}
This paper provides a brief introduction of domestication and foreignization as well as an exploration into both strategies in the Chinese-English translation of the white paper on anti-corruption through which the feasibility of adopting them can be exemplified, expounded on and justified while attention can be drawn to these two strategies when other translators are reading its English version or translating similar documents. It attempts to explore the reasons behind the choice of the two strategies and to provide different categories of examples with the intention of helping other translators understand well under what circumstances domestication or foreignization should be adopted.
\end{abstract}

Keywords: Domestication; Foreignization; Strategies; Translation of the white paper on anti-corruption

\section{Introduction}

Having made great achievements in economic and social development during the 11th Five-Year Plan period, China has formulated the 12th Five-Year Program, which emphasizes the necessity to intensify efforts to combat corruption and promote clean government. Later China expressed its resolve to strengthen the fight against corruption on 29th, December, 2010 as it released its first ever white paper on anti-graft efforts, entitled "China's Efforts to Combat Corruption and Build a Clean Government". Now that China has become a major developing power, its every movement pulls at the heartstrings of the world. Naturally, this white paper has attracted attention from both home and abroad. The white paper is aimed at helping eliminate bias against and misunderstanding of China's anti-graft battle as it details both achievements and problems; consequently, translating the report on anti-corruption is of great significance. What is more, the Chinese government is paying more attention to China's image and more committed to the publicity of China's culture and policies, which will be better realized with a faithful and appropriate translation of its political documents since it will help people understand China in a correct, objective and comprehensive way.

With the above reasons taken into account, the Chinese-English translation (hereinafter referred to as C-E translation) of political documents is doubtlessly of great significance in getting across the messages of the Chinese government. The translation of such documents involves two main translation strategies: domestication and foreignization. To ensure a better understanding from the outside world, some translators favour domesticating translation as the main strategy while others are supporters of foreignizing translation as the dominant method, claiming that it can give more publicity to some expressions with Chinese characteristics and thus better promote China's ideas. This has aroused a heated debate over these two approaches in the C-E translation of the political documents.

Corruption is a sensitive issue, and the white paper shows China has a more open and cooperative attitude toward the 
problem. However, few researches can be found concerning the C-E translation of the white paper on anti-corruption despite the fact that the white paper itself has received wide attention. There are researches concerning other whiter papers, but few of them are done from the perspective of translation strategies. In this paper, the author focuses on the strategies of domestication and foreignization in the report, though for some previous studies that do include these two strategies, more emphasis is laid on the analysis of how they are used rather than the reason for the adoption of different strategies.

In the paper, taking the C-E translation of the white paper on anti-corruption as an example, the author attempts to give a brief study of the two translation strategies which provide both cultural and linguistic guidance, offering some insights into which strategy to choose in a certain situation.

\section{An Overview of the White Paper on Anti-corruption}

\subsection{Brief introduction to the white paper on anti-corruption}

The white paper on anti-graft efforts introduces principles, working mechanisms and legal framework for China's anti-graft system. It also sets out the progress made in combating corruption and international anti-graft cooperation. China's efforts to combat corruption and build a clean government, which is managed systematically and promoted comprehensively, have "achieved results," the report said. But the document warned that the task of curbing corruption remains tough. The white paper also acknowledges the role of Internet in curbing corruption, lauding it as a "fast, influential and widespread" means of supervision.

\subsection{Significance of the white paper on anti-corruption}

In the present society, anti-corruption is not only a problem facing a single party or a single nation, instead, it has become a global issue, a more transparent issue in the international arena. The release of such a white paper presents a brighter image of China, which can exert a positive impact on upgrading its international image and attracting overseas investment. Its issue signifies that China's efforts to combat corruption and build a clean government have entered a new stage.

Firstly, the release of the white paper on anti-corruption is quite significant internationally. With reform and opening up as well as China's raised global status, the international community has given close attention to its anti-graft efforts. The stereotyped mentality and insufficient publicity have bred bias and misunderstanding, thus a few number of people have not developed a correct, objective and comprehensive understanding of China's reality. The white paper is a response to the international concern, answering questions and removing doubts. It is conducive to eliminating those biases and misunderstanding about China's anti-graft battle as it details both achievements and problems.

Secondly, the white paper is of great domestic significance. The Chinese people are highly concerned about the government's efforts to combat corruption and build a clean government. As some serious cases of graft among party officials were revealed, some began to view the whole issue in a passive and pessimistic perspective. Stating a large number of objective facts to demonstrate that China has achieved remarkable progress since reform and opening up endeavour, especially since the 21st century, the white paper made it clear that fighting against corruption is the consistent stand of the CPC and the Chinese government. This has effectively addressed domestic pessimism, corrected some biased opinions, and strengthened people's confidence in a timely manner.

Thirdly, the issue of the white paper on anti-graft is highly relevant to the reality. The statements in the paper represent not only the scientific judgments of the Chinese government, but also its solemn commitment. The paper's form, timing of issue and its content are all geared to the national condition, which is an innovation in China's struggle over the past years to build a clean government.

Lastly, as a landmark, the paper is of great historic importance. Throughout the history of revolution, construction and reform, the Party has always conscientiously made the work of combating corruption and building a clean government a priority task. Though the objective circumstances might be different in various historic stages, the Party and the government has remained sober-minded and resolute in taking forceful measures against corruption. The prospect of combating corruption and building a clean government in China is bright. In such a sense, the release of the white paper on anti-corruption enjoys, without doubt, profound historic significance.

\section{Domestication and Foreignization in the C-E Translation of the White Paper on Anti-corruption}

\subsection{Definitions of domestication and foreignization}

The roots of the two terms can be traced back to the famous German theologian and philosopher Friedrich Daniel Ernst Schleiermacher, who put forward his ideas in his famous lecture On the different ways of Translating given in 1813. In the lecture, he argued that there were only two different methods of translation, 
"Either the translator leaves the author in peace as much as possible, and moves the reader towards him; or he 1eaves the reader in peace as much as possible, and moves the author towards him." (Lefevere, 1977, p.74)

Laurence Venuti provided peop1e with brand-new perspectives in his book The Translator's Invisibility in 1995. In the book, Laurence defined "a domesticating method" as "an ethnocentric reduction of the foreign text to target-language cultural values, bringing the author back home" and "a foreignizing method" as "an ethnodeviant pressure on those values to register the linguistic and cultural difference of the foreign text, sending the reader abroad" (Venuti, 1995, pp. 19-20).

Venuti (1995) studied domesticating method and foreignizing method in the context of society, politics, ideology and history, and revealed that fluent translation had always been in a commanding position in the translation history in the western world. He argued that domesticating method dominates Anglo-American culture which recommends fluent translating. Under the norms of fluency, the target text is free of the slightest trace of translation and is read as if it had been written by the original author in the target language. The differences existing between the two languages are replaced by something familiar to the target language reader. According to Venuti (2004, p. 203), domesticating translations "conform to values currently dominating the target-language culture, taking a conservative and openly assimilationist approach to the foreign text, appropriating it to support domestic canons, publishing trends and political alignments." On the contrast, foreignizing translation may "resist and aim to revise the dominant by drawing on the marginal, restoring foreign texts excluded by domestic canons."

In line with Venuti's viewpoint, Mark Shuttleworth and Moira Cowie gave a definition to domestication in Dictionary of Translation Studies as"a term to describe the translation strategy in which a transparent, fluent style is adopted in order to minimize the strangeness of the foreign text for TL ( target language) reader.'In the early stage of the nineteenth century, foreignizing translation rose in Germany. Schuttleworth and Cowie defined foreignization as "a term to designate the type of translation in which a TT(target text) is produced which deliberately breaks target conventions by retaining something of the foreignness of the original" (Shuttleworth \& Cowie, 2004, p. 59) .

Domesticating means bringing the foreign culture closer to the reader in the target culture, making the text recognizable and familiar to the reader. It provides the reader with a native reading experience. Foreignizing, on the other hand, means taking the reader over to the foreign culture, making him or her see the cultural and linguistic differences. A foreignized translation should be deviant enough from the norms and values in the target language culture so that it can stage an exotic reading experience. Domestication and foreignization represent two orientations in translation. The former is TL-culture-oriented, and the latter is SL-culture-oriented.

\subsection{Different opinions over domestication and foreignization}

In the field of translation, there has long been a hot debate over domestication and foreignization, which have been the focus of attention since their appearance. Many translators and scholars are trying to find a balancing point in the use of the two strategies. This phenomenon is pervasive both in the west and in China. A further and closer look at these debates will provide lessons and insights so that an analysis of domestication and foreignization in the Chinese-English translation of the white paper will be better conducted.

\subsubsection{Opinions in the west}

In the contemporary international translation field, Eugene Nida is regarded as the most representative supporter of domesticating translation. Nida pointed out that translation should first avoid the possible misunderstanding by the receptors, thus making clear the tangible reference to present-day circumstances of life. Nida took a reader-oriented approach, stating what was involved in the process of translating was"reproducing in the receptor language the closest natural equivalent of the source-language message, first in terms of meaning and secondly in terms of style"(Nida \& Taber, 1974, p. 12). Nida's idea is of far-reaching significance in the history of translation, which shed light upon domestication and foreignization from a comprehensive perspective and inspired numerous followers.

A staunch supporter of foreignization is Lawrence Venuti, who first coined the two terms: domesticating and foreignizing translation in his influential book The Translator's Invisibility. According to him, foreignizing method seeks to restrain the ethnocentric violence of translation, and it is a strategic cultural intervention in the current state of world affairs. Venuti, as a matter of fact, regarded foreignizing method as a form of resistance against ethnocentrism and racism, culture narcissism and imperialism (Venuti, 1995, p. 20). Venuti's viewpoint has been attracting international attention. As Edwin Gentzler writes in his book Contemporary Translation Theories, "Venuti's international following is quite strong, particularly in Europe and Latin America" (Gentzler, 2004, p. 42). 


\subsubsection{Opinions in China}

In China, there have appeared several important periods of translation, during which either strategy enjoyed dominance as the time changed. In the 1930s Lu Xun put forward the translation principles of "faithfulness over smoothness" (Zhao, 1994, p. 19). With open preference for "rigid translation", Lu adopted language that was quite westernized in his translation. In line with Lu's viewpoints, Qu Qiubai upheld foreignizing translation, claiming it would retain the foreign spirit and enrich the Chinese language. However, Lu's translation theory was fiercely attacked by Liang Shiqiu, who criticized Lu's "rigid translation" as "dead translation", saying that "reading Lu's translation is like reading a map, and one has to search for the position of the grammatical elements with one's figure"(ibid.: 18). Also strongly opposed to Lu's principle, Zhao Jingshen argued that since readers wanted something easy to read, some deviations from the original were acceptable so long as he could produce a smooth version that would reduce the foreignness of the source text. Thus He would "rearranges Yan's three phases in a new order, as follows: expressiveness, faithfulness, elegance". (Luo, 1984, p. 267).

Domestication has enjoyed a dominant role for nearly half a century until Liu Yingkai explicitly pointed out that 'Domestication is a wrong path to translation' (Y.K. Liu, 1987, p. 23). He argues that domesticating translation, by assimilating the national characteristics of the ST, distorts the ST. Xu Yuanchong, on the contrary, favors domestication. Many other translators and scholars hold their own stances over domestication and foreignization. For example, Guo Jianzhong believes that foreignization might surpass domestication in the future (Guo, 1998, p. 18). Up till now, the debate is still going on.

The white paper on anti-corruption serves a suitable and applicable context to further analyze the adoption of the two strategies. Is it true that one surpasses the other like many of the above-mentioned scholars suggested or is it possible to strike a balance? Exactly, how are the two adopted in translating such a political document so that people are able to understand it in a correct, objective and comprehensive way?

\subsection{Domestication and Foreignization in the C-E translation of the white paper on anti-corruption}

\subsubsection{Domestication in the C-E translation of the white paper on anti-corruption}

Being target-language-oriented, domesticating means bringing the foreign culture closer to the reader in the target culture, making the text recognizable and familiar. The use of domesticating translation in the C-E translation of the white paper on anti-corruption could be analysed from the lexical, syntactic and textual level. More details are as follows:

\subsubsection{Domestication at lexical level}

Expressions with Chinese characteristics constitute one of the most distinctive features of political documents such as the white paper. Some expressions are exclusive to the Chinese language, and without domestication, the translation would fail to get across the message of the original text.

\subsection{Expressions with different English translations}

In the white paper on anti-corruption, some expressions are repeated many times in the Chinese text, such as ‘加强”, ‘制 定”, ‘完善”, ‘坚持' and ‘不断”. However, a common phenomenon is that such expressions are usually rendered into different English words due to proper collocation. In order to convey the exact meaning of the white paper, the domesticating method is indispensable. As '加强' is most frequently repeated in the white paper, it serve as a representative example. Below is a chart listing its different versions of translation, with some examples extracted from the white paper as follows:

$<$ Table 1 about here>

Since there are too many examples about the word ‘加强', only some examples are selected to analyze the domesticating strategy. The examples chosen are as follows:

E.g.1.中国制定了一系列法律法规制度, 以加强对领导干部行使权力的制约和监督。(Section 3, paragraph 3)

China has enacted a series of laws and regulations to strengthen restraint and supervision over the exercise of power by leading cadres.

E.g.2. 与世界各国、各地区和有关国际组织加强合作。(Section 8, paragraph 1)

... to enhance cooperation with other countries, regions and relevant international organizations.

E.g.3. 加强公民道德建设和廉政文化建设...... (Section 1, paragraph 5)

Efforts are being made to raise the ethical standards of citizens and foster a culture of integrity... 
E.g.4. 反对腐败，加强廉政建设，是中国共产党和中国政府的坚定立场。(Preface，paragraph 1)

It is the firm stance of the Communist Party of China $(C P C)$ and the Chinese government to combat corruption and build a clean government.

The chart combined with the examples shows clearly that one Chinese expression could correspond with many different English expressions. The examples demonstrate that the English translation is largely determined by other components following the word ‘加强'. Appropriately matched translations help bring the text closer to the target readers.

\subsection{Four-word expressions}

Four-character expressions are prevalent in the Chinese language. Since its main function is to persuade and call for action, political writing makes the best of the four-character expressions to be more eloquent and persuasive. Although the exact same effect could not be achieved in the target text through domestication, similar feelings could still be aroused. For instance:

E.g.5. ……逐步形成内容科学、程序严密、配套完备、有效管用的反腐败和廉政建设法律法规制度体系。 (Section 3, paragraph 1)

...gradually establishing a legal framework for combating corruption and building a clean government with scientific contents, rigorous procedures, well-matched regulations and effective administration.

In the example, the use of the four four-character expressions in the Chinese version comprise distinct parallel structures, which are very convincing as well as substantial. In order to reproduce the same effect, the English version uses four parallel structures composed of the modifier and the noun to impress the readers. Other than that, noun phrase is more widely used in English, thus domestication is adopted in a quite appropriate way here.

\subsection{Explanation}

Many expressions in the white paper demand a good knowledge of China's conditions and systems. Without necessary explanations added in the English translation, some words could never be understood by the target readers. To ensure that the message of the Chinese government is correctly and comprehensively received, the approach of explanation is indispensable as it provides some background knowledge or details which will help eliminate misunderstanding. For example:

\section{E.g.6.中国政府设有专门的信访机构，受理公民提出的检举控告和意见建议。（Section 4，paragraph 7）}

The governments at all levels in China have set up special organs to handle letters and calls of complaints as well as opinions, suggestions and accusations from the people.

If '信访机构' is translated into organs of letters and visits with no explanation, it would be ambiguous, thus difficult to understand. With the explanation added, readers will surely have a clearer picture of the organ, which will help publicize the ideas of the Chinese government. Under such circumstances, domesticating translation with complementary phrases contributes to a better understanding among the receptors.

\subsection{Paraphrase}

Political documents can easily witness the ubiquitousness of expressions with Chinese characteristics. These phrases feature strong culture-bound images, and only with the adoption of paraphrase, a native reading experience can be rendered. Such examples are ample in the white paper on anti-corruption:

E.g.7.中国坚持一手抓发展经济, 一手抓惩治腐败..... (Section 1, paragraph 3)

China has implemented the policy of punishing corruption while making efforts to develop the economy...

E.g.8.中国政府......纠正有令不行、有禁不止等行为...... (Section 6, paragraph 9)

The Chinese government...to fight against disobeying orders and defying prohibitions...

In the first example, the sentence pattern of '一手...... - 手' is of distinctive Chinese characteristics. It often appears in political documents, government reports in particular. When translated into English, the image of '手' is omitted, and the official English version uses "while" to combine the two actions, which also convey exactly what the original text means without causing any confusion. In the second example, “有...... 不'is also unique to the Chinese language, thus it is hard to reproduce the source text without breaking the original sentence structure. An in-depth comprehension of the source text can enable translators to paraphrase the sentences and produce a translated version that will not make the readers feel alienated. 


\subsubsection{Domestication at syntactic level}

The white paper on anti-corruption, with the frequent use of lengthy and complicated sentences, causes great difficulty for translators. Therefore, much change has to be made at the syntactic level, which could be seen mainly in the translation of sentences with seriate verbs.

In terms of syntactic structure, there is a huge difference between the Chinese language and the English language. Sentence with seriate verbs, which means that two or more verbs are used simultaneously as predicates in one sentence, are common in the Chinese language. However, In English, one sentence only contains one single predicate. In the white paper on anti-corruption, there are many sentences with seriate verb and obviously the Chinese syntactic structure could not be maintained if a readable version is desired. Therefore, the strategy of domestication should be adopted. Here is an example from the white paper:

E.g.9.中国共产党和中国政府坚持在法律和纪律面前人人平等, 严肃查处党员干部和国家工作人员中的腐败行为, 保持 惩治腐败的强劲势头。(Section 6, paragraph 1)

Upholding the principle that everyone is equal before the law and discipline, the CPC and the Chinese government are serious in dealing with corruption among cadres who are Party members and state functionaries, maintaining a stern momentum in the checking of corruption.

In the Chinese version, there are three verbs一“坚持”, “查处”, “保持”. In the English version, by turning the verb “坚持” into a present participle 'upholding', an adjoint adverbial is created. At the same time, another verb '保持' is translated into 'maintaining', which precedes a subordinate clause, thus succeeding in transforming the Chinese syntactic structure into the English counterpart without meaning shift.

\subsubsection{Domestication at textual level}

The English language is hypotactic while the Chinese language is paratactic, which represents a core difference of the two languages. According to Liu Miqing, a hypotactic language refers to one that makes use of some language forms (lexical and morphological) to connect the phrases or sentences and emphasize the cohesion in the form of the language; a paratactic language refers to one that achieves such cohesion by means of the semantic or logical relationship rather than the forms, with the emphasis on the coherence. (M.Q. Liu, 2005, p. 74)

In the white paper on anti-corruption, the cohesive devices adopted are mainly reference and substitution.

\subsection{Reference}

The Chinese language tends to witness more repetition than English. In a political document like the white paper, repetition is more frequently used in order to bring more eloquence and persuasion to the text. Consequently, when translating sentences with repetition, how to deal with these somewhat redundant words and sentences constitutes a major challenge to the translator.

In a text, a referenced item and a referent can explain each other. This kind of relationship is called reference. reference plays a crucial role in resolving the afore-mentioned problem. For example:

\section{E.g.10.自 1993 年以来，中共中央每年通过中央纪委全会向全党全国部署反腐倡廉工作.（Section 2，paragraph 3）}

Since 1993 the CPC Central Committee has been making arrangements for the work of combating corruption and building a clean government in the whole Party and country at annual plenary sessions of its Central Commission for Discipline Inspection.

In the example, '中央' is repeated, yet in the English translation, the second 'the CPC Central Committee' is replaced by the possessive determiner 'its', successfully attaining formal cohesion.

\subsection{Substitution}

Substitution refers to the technique of substituting some components of the sentence-whether a word, a phrase or a clause, with the substitute. With the adoption of such a method, unnecessary repetition can be avoided to a great extent, and as a result, the language will be much more lucid and cohesive. For example:

E.g.11.中国今后将更加注重法律法规制度的贯彻实施，并根据形势发展的需要继续制定新的、修订原有的反腐败和廉政 建设法律法规制度...... (Section 3, paragraph 7)

China will attach greater importance to the implementation of laws and regulations, while enacting new laws and regulations and amending existing ones in this regard in accordance with the changing situations in the future.

The use of 'ones' as a substitute in the translation here serves to avoid the redundant words of 'laws and regulations' again and provides an appropriate link, achieving the formal cohesion which is essential to English. 


\subsubsection{Foreignization in the C-E translation of the white paper on anti-corruption}

As it is source-language-oriented, foreignization means to take the reader over to the foreign culture, making him or her see the cultural and linguistic differences. A foreignized translation should be deviant enough so that it can stage an exotic reading experience. Literal translation has always been regarded as the major means of foreignizing translation. Yet in the white paper on anti-corruption, foreignization is realized more by some distinctive English with Chinese characteristics than by means of literal translation. The Chinese-culture-bound expressions are listed in the following chart:

<Table 2 about here>

The expressions listed in the chart feature strong culture-bound images, which convey what the Chinese government wants to promote. The white paper is aimed at helping eliminate bias and misunderstanding about China's anti-graft battle, and with the adoption of foreignization, it can give more publicity to China's ideas and policies by widely disseminating some Chinese-culture-bound expressions.

\section{Analysis of Reasons for the Adoption of the Two Strategies}

The debate over domestication and foreignization in the C-E translation of political documents is still going on, with some scholars advocating the former and others supporting the latter. In fact, both domesticating and foreignizing strategies have their advantages and limitations. Domesticating translation is easier for the readers to understand and accept. However, the smoothness of the TL are often achieved at the expense of the cultural and stylistic implications of the SL. Foreignizing translation preserves the ST features and its culture, but alien cultural images and linguistic features may cause difficulties in comprehension for the readers, making them feel estranged. In a word, both domestication and foreignization entail losses, as losses are inevitable in the translation process.

Moreover, factors influencing the choice of domestication and foreignization include, for example, the text type, the translation purpose, the target reader, the translators' cultural attitude, etc. It is hard to say which one is better if the condition under which a translation is done is not taken into account. In C-E translation, with the help of domestication, the translators can produce a smooth and readable version that is familiar to readers while through the adoption of foreignization translators aim to introduce the Chinese culture to the western readers as much as possible, adhering to the SL-culture-oriented principle.

Whether it is domestication or foreignization, a choice of the strategy is made out of good reasons. If we take into consideration the situation in which a translating activity takes place, we will find that each translation strategy can be justifed in its own right. Knowing why translators choose different strategies will help us understand when to domesticate and when to foreignize in translating similar documents. In his article 'Foreignization and Domestication: Cultural Factors in Translation', Guo Jianzhong summarizes reasons for adopting domestication and foreignization.

\subsection{Reasons for domestication}

1). It is unreasonable to impose the source language norms on the target language; likewise, it is also dangerous to impose the SL culture system on the TL culture system. Therefore, translation should overcome both language and cultural barriers.

2). Since translation serves for intercultural communication, one of the major responsibilities of translators is to avoid cultural collision, which might lead to misunderstanding in various forms. Therefore, the ideological implication should be taken into full consideration before being transferred into another culture.

3). It would be easier for readers to comprehend the translation if its content and form are within the their knowledge range. Consequently, the translators should transfer the source culture as much as possible. Meanwhile, the translators can also help eliminate intercultural misunderstanding by bringing the SL cultural implication to TL readers.

4). Translator should not hold too high expectations for the intelligence and imagination of the target readers, insisting that they should approach closer to the world of source language authors. Rather, they should bring the source culture as close as possible to the target readers.

5). While translating, not every word is guaranteed a correspondent in the target language. Even when there is such a correspondent, it may fail to achieve the same effect as the original word. In this sense, translators should manage to acquire cultural equivalence. 


\subsection{Reasons for foreignization}

1). It is necessary to enable target readers to understand the foreign culture, which is also their purpose of reading translated works.

2). Translators should have confidence in target readers for their ability to appreciate the uniqueness of foreign culture with their intelligence and imagination.

3). The source culture transferred into the target culture will enrich ways of expression of the latter.

4). Translation should act as a bridge for intercultural communication, which is its very main purpose.

5). If it failed to reproduce the source language world, the translated work could not call itself faithful to the original.

In light of the reasons listed above, a conclusion could be drawn that all translators are devoted to helping the target readers bridge the gap between two different cultures. Different translation strategies are adopted on the basis of different answers to the following questions - whether the target readers have enough imagination and intellectual competence to understand the foreign culture, whether communication between cultures should focus on the 'assimilation' of the foreign cultures or the maintenance of them.

The examples in the former chapters would suffice to demonstrate that, in the translation of the white paper on anti-corruption and other similar political documents, domesticating translation is undoubtedly favored. This is mainly determined by the function of such documents - to offer the international society a panoramic view of China, to win support and cooperation from the world and to remove certain bias and misunderstanding. To this end, domestication is adopted in most cases to reproduce what the Chinese government would like to promote in a way that is familiar to foreign readers through means of explanation, paraphrase, structural changes and substitution. With regard to some expressions that the Chinese government would like to stress or that cannot be rendered to convey the original message by whatever means, foreignizing translation can be adopted.

\section{Conclusion}

Both strategies play an important role in intercultural communication, and though they seem to be contradictory to each other., if combined together, they can coordinate well to achieve the purpose of enhancing communication between cultures. The two can coexist with each other and a good translation entails both. The debate over these two strategies is still pooling strength. Due to its distinctive features and function, the political documents are of great significance in the debate. The Chinese government now is becoming more concerned with China's image and more committed to the publicity of China's culture and policies with the intention of playing a more influential and active role in international affairs. With China's closer engagement in the global stage, the translation of the political documents occupies an increasingly important position. Through the illustration of examples from the white paper on anti-corruption, this paper exemplifies the feasibility of these two strategies in political documents and explores the reasons behind the choice of

different translation strategies. Domestication is not equivalent to total assimilation of the source text, with no track of foreign culture. Foreignization is not equivalent to literal translation, which might produce a translated work that is not readable. A possible solution is to strive for a balance between them, which calls for strenuous and persistent efforts. For different texts, the balancing point will be different. In the translation of the white paper on anti-corruption, it can be concluded that domestication is preferred to foreignization with no doubt. With regard to problems concerning domestication and foreignization in the white paper on anti-corruption, this paper serves as a good reference with appropriately and carefully selected examples.

\section{References}

Gentzler, E. (2004). Contemporary Translation Theories $\left(2^{\text {nd }}\right.$ ed.). Shanghai: Shanghai Foreign Language Education Press.

Guo, Jianzhong. (1998). "Cultural Factors in Translation: Foreignization and Domestication". Journal of Foreign Languages. (2): 18-20

Lefevere, A. (1977). Translating Literature: The German Tradition from Luther to Rosenzweig. Assen: Van Gorcum.

Liu, Miqing. (2005). A Comparative Study on Chinese and Western translation theories. Beijing: China Translation \& Publishing Corporation.

Liu, Yingkai.(1987). Domestication is a wrong path to translation. Modern Chinese (2): 23-26.

Luo, Xinzhang. (1984). The Collection of Translation Theory. Beijing: The Commercial Press 
Nida, E. A. \& Taber, C.R. (1974). The Theory and Practice of Translation. Leiden: E. J. Brill.

Shuttleworth, M. \& Cowie, M. (2004). Dictionary of Translation Studies. Shanghai: Shanghai Foreign Language Education Press.

The Chinese-English Translation of the White Paper on Anti-corruption. [Online] Available:

http://www.china.com.cn/ch-book/. (Dec 29th, 2010)

Venuti, L. (1995). The Translator's Invisibility: A History of Translation. London and New York: Routledge. http://dx.doi.org/10.4324/9780203360064

Venuti, L. (2004). The Translator's Invisibility: A History of Translation (2 ${ }^{\text {nd }}$ ed.). Shanghai: Shanghai Foreign Language Education Press.

Zhao, Junfeng. (1994). “An Analysis on the Debate of Translation Criterion to the 1930's ". Journal of Foreign Languages. (5): 18-22.

Table 1. A List of Different English Translations of ‘加强”

\begin{tabular}{|c|c|c|c|}
\hline 序号 & Chinese & English Translation & Frequency \\
\hline 1 & \multirow{5}{*}{ 加强 } & strengthen & 17 \\
\hline 2 & & enhance & 6 \\
\hline 3 & & intensify/tighten & $1 / 2$ \\
\hline 4 & & improve & 3 \\
\hline 5 & & $\begin{array}{l}\text { efforts are being made to, } \\
\text { make great efforts to }\end{array}$ & 3 \\
\hline 6 & & Not translated & 5 \\
\hline \multicolumn{3}{|l|}{ Total } & 37 \\
\hline
\end{tabular}

Table 2. The Chinese-culture-bound expressions

\begin{tabular}{|c|c|}
\hline Chinese & English \\
\hline 三反运动, 五反运动 & Three-anti Campaign, Five-anti Campaign \\
\hline 建言献策 & making suggestions and offering advices \\
\hline 双重领导 & the dual leadership \\
\hline 巨额财产来源不明 & $\begin{array}{l}\text { holding a huge amount of property with an } \\
\text { unidentified source, }\end{array}$ \\
\hline $\begin{array}{l}\text { 明确警告、严重警告、撤销党内 } \\
\text { 职务、留党察 看和开除党籍 }\end{array}$ & $\begin{array}{l}\text { explicit warning, stern warning, removal from post } \\
\text { within the Party, probation within the Party and } \\
\text { expulsion from the Party }\end{array}$ \\
\hline 记大过 & recording of major demerit \\
\hline 思想道德防线 & the ideological and moral defense line \\
\hline 一个部门一本预算 & one budget for one department \\
\hline 自治区、直辖市 & $\begin{array}{l}\text { autonomous regions, municipalities directly under } \\
\text { the central government }\end{array}$ \\
\hline 以廉为荣、以贪为耻 & honoring integrity and disgracing corruption \\
\hline
\end{tabular}

